\title{
Pengaruh Pembelajaran Matematika Realistik Berbasis Keterampilan Abad 21 Terhadap Hasil Belajar Siswa Kelas VII MTs Muallimat NW Pancor
}

\author{
Siti Nurmina ${ }^{1}$, Nyoman Sridana ${ }^{2}$, Junaidi ${ }^{3}$ \\ ${ }^{1}$ Mahasiswa Pendidikan Matematika, FKIP, Universitas Mataram, Mataram \\ 2,3 Dosen Pendidikan Matematika, FKIP, Universitas Mataram, Mataram \\ *email: sitinurmina325@gmail.com
}

\begin{abstract}
This study aims to determinethe influence of 21-st century realistic mathematics learning skill-based on student learning achievement of class VII MTs Muallimat NW Pancor academic year 2019/2020. This research use an experimental study with a Posttest Only Control Group Design. Population in this study consisted of 6 classes and sample of this study is consisted of students from class VII-A and VII-B which are selected by using Random Sampling Cluster technique. Class VII-A as a control class is used conventional learning method and class VII-B as an experimental class by applying realistic mathematics learning based on 21-st century skills. Student learning achievement were obtained through a final test (posttest). The instrument of this study using a test consisted of 4 essay questions. The data obtained was analyzed using ttest. Based on data analyzed,it can be concluded that there is an influence of 21 -st century realistic mathematics learning skill-based on student learning achievement of class VII MTs Muallimat NW Pancor academic year 2019/2020
\end{abstract}

Keywords: Realistic Mathematics; 21st Century Skills; Learning Outcomes

\begin{abstract}
Abstrak
Penelitian ini bertujuan untuk mengetahui pengaruh pembelajaran matematika realistik berbasis keterampilan abad 21 terhadap hasil belajar siswa kelas VII MTs Muallimat NW Pancor Tahun Ajaran 2019/2020. Jenis penelitian yang digunakan adalah penelitian eksperimen dengan desain penelitian Posttest Only Control Group Design. Populasi dalam penelitian ini adalah seluruh kelas VII MTs Muallimat NW Pancor tahun ajaran 2019/2020 yang terdiri dari 6 kelas. Pengambilan sampel menggunakan Cluster Random Sampling, didapatkan sampel dalam penelitian ini adalah siswa kelas VII-A dan siswa kelas VIIB, kelas VII-A sebagai kelas kontrol digunakan pembelajaran konvensional dan kelas VII-B sebagai kelas eksperimen digunakan pembelajaran matematika realistik berbasis keterampilan abad 21. Hasil belajar matematika siswa diperoleh melalui tes akhir (posttest). Instrumen penelitian yang digunakan sebagai tes sebanyak 4 butir soal uraian. Teknik analisis data yang digunakan adalah uji-t. Berdasarkan hasil analisis data dapat disimpulkan bahwa terdapat pengaruh penerapan pembelajaran matematika realistik berbasis keterampilan abad 21 terhadap hasil belajar siswa kelas VII MTs Muallimat NW Pancor Tahun Ajaran $2019 / 2020$.
\end{abstract}

Kata Kunci: Pembelajaran Matematika Realistik; Ketrampilan Abad 21; Hasil Belajar

\section{PENDAHULUAN}

Matematika merupakan ilmu universal yang mempunyai peran penting dalam berbagai disiplin ilmu dan mengembangkan daya pikir manusia serta mendasari perkembangan teknologi modern (Mashuri, 2019). Untuk menguasai dan mencipta teknologi di masa depan diperlukan penguasaan matematika yang kuat sejak dini. Oleh karena itu, mata pelajaran matematika perlu diajarkan pada semua jenjang pendidikan. Penguasaan 


\section{Mandalika Mathematics and Education Journal}

Volume 3 Nomor 1, Juni 2021

e-ISSN 2715-1190 | | p-ISSN 2715-8292

DOI: http://dx.doi.org/10.29303/jm.v3i1.1956

ilmu matematika sangat dibutuhkan oleh siswa baik dalam pendidikan formal maupun dalam kehidupan sehari-hari karena begitu banyak aktivitas yang melibatkan ilmu matematika.

Melihat begitu pentingnya peran matematika, maka hasil belajar matematika perlu mendapat perhatian yang serius. Berdasarkan observasi awal yang dilakukan di sekolah Mts Muallimat NW Pancor menunjukkan bahwa kelas VII memperoleh hasil belajar matematika yang termasuk dalam kategori cukup rendah. Hal ini terlihat dari hasil ujian tengah semester siswa tahun pelajaran 2019/2020 pada mata pelajaran matematika kelas VII dimanasiswa mendapat nilai di bawah Kriteria Ketuntasan Minimal.

Selain itu data hasil Ujian Nasional pada mata pelajaran matematika menunjukkan bahwa nilai matematika siswa terbilang rendah baik pada tingkat nasional mupun provinsi seperti yang terlihat pada Tabel 1.

Tabel 1. Data Hasil UN Mata Pelajaran Matematika

\begin{tabular}{clcc}
\hline NO & \multicolumn{1}{c}{ Materi yang Diuji } & Provinsi & Nasional \\
\hline 1 & Bilangan & 30,29 & 36,21 \\
\hline 2 & Aljabar & 41,08 & 49,32 \\
\hline 3 & Geometri dan Pengukuran & 37,70 & 39,93 \\
\hline 4 & Statistika dan Peluang & 46,99 & 54,55 \\
\hline \multicolumn{2}{r}{ Sumber : Puspendik Kementerian Pendidikan dan Kebudayaan }
\end{tabular}

Berdasarkan Tabel 1. bahwa materi matematika dari empat sub materi yang diujikan yaitu bilangan, aljabar, geometri dan pengukuran, statistika dan peluang baik pada tingkat nasional maupun provinsi memiliki nilai rata-rata berada di bawah 60 .

Berdasarkan hasil wawancara yang dilakukan dengan guru mata pelajaran matematika dan siswa kelas VII MTs Muallimat NW Pancor, di dapatkan informasi bahwa siswa kelas VII merasa bahwa mata pelajaran matematika itu sulit. Menurut penuturan guru mata pelajaran matematika, siswa kesulitan dalam memahami soal cerita yang diterapkan dalam kehidupan sehari-hari dan siswa juga masih kurang dalam memahami konsep sehingga soal-soal pengembangan kurang bisa di pahami dan di selesaikan oleh siswa. Hal inilah yang menyebabkan rendahnya hasil belajar siswa.

Selain itu siswa juga masih kurang dalam memahami konsep sehingga soal-soal pengembangan kurang bisa di pahami dan di selesaikan oleh siswa. Membangun makna atas suatu konsep bagi peserta didik merupakan sasaran utama dalam kegiatan pembelajaran matematika (Elis, 2015). Untuk mencapai sasaran utama pembelajaran tersebut, guru dituntut dapat menciptakan suasana belajar yang melibatkan siswa secara aktif dalam berpikir, memahami materi dan mengembangkan kemampuan menyelesaikan masalah matematika. Akan tetapi pada kenyataannya masih banyak guru matematika yang belum sepenuhnya dapat menciptakan suasana belajar yang demikian. Penyebabnya adalah guru masih menerapkan cara mengajar kurang variatif, 
guru tidak mengaitkan materi dengan situasi realistik yang biasanya dijumpai dalam kehidupan sehari-hari. Cara mengajar guru (konvensional) adalah guru lebih berperan aktif di kelas yaitu pendekatan yang berpusat pada guru (Friscilla, 2013).

Pendekatan yang berpusat pada guru menurut Sanjaya (2017) adalah pendekatan pembelajaran yang pelaksanaanya diatur dan ditentukan oleh guru. Dengan kata lain gurulah yang menjadi pusat dalam kegiatan belajar mengajar. Jika guru menerapkan pendekatan pembelajaran ini terus-menerus maka pembelajaran menjadi monoton dan membosankan. Apabila mata pelajaran matematika yang bersifat abstrak disampaikan secara monoton dan membosankan dikhawatirkan tidak dapat dipahami dengan baik oleh siswa, sehingga berdampak pada hasil belajar yang diperoleh siswa.

Oleh karena itu, melalui kurikulum 2013 pemerintah merancang pembelajaran yang tidak lagi berpusat pada guru melainkan pembelajaran yang berpusat pada siswa. Menurut Urip (Friscilla, 2013) pendekatan yang berpusat pada siswa adalah pembelajaran yang melibatkan penciptaan lingkungan dan pengalaman yang memungkinkan para siswa mencari, menemukan, dan mengkontruksi pengetahuan. Untuk itu, dalam proses belajar mengajar sebaiknya guru menggunakan pendekatan yang dapat menghubungkan atau mengkaitkan antara konsep-konsep matematika dengan kehidupan sehari-hari. kegiatan belajar mengajar. Sehingga siswa akan lebih mudah memahami konsep matematika yang diajarkan oleh guru. Hal ini dapat mempengaruhi hasil belajar yang di peroleh siswa.

Salah satu pendekatan yang dirasa cocok dan dapat digunakan sebagai alternatif dalam pelaksanaan pembelajaran matematika di sekolah adalah pendekatan pembelajaran matematika realistik atau yang lebih dikenal dengan nama Realistic Mathematic Education (RME). Pembelajaran Matematika Realistik (Realistic Mathematic Education) merupakan teori belajar mengajar dalam pendidikan matematika (Turmuzi, 2017). Dimana dalam pembelajaran matematika realistik siswa dituntut lebih aktif dalam proses pembelajaran sehingga dapat mengembangkan kemampuan berfikir siswa terutama kemampuan dalam memahami konsep matematika yang bersifat abstrak. Hal ini sejalan dengan pembelajaran pada abad 21, dimana siswa harus memiliki kemampuan yang lebih agar mampu bersaing di era-globalisasi saat ini. Karena pada zaman ini jika hanya memiliki kemampuan dasar saja tidak cukup untuk dapat berkompetensi di abad 21. Untuk dapat menghadapi abad 21 Indonesia sebagai negara yang maju harus dapat mengimbangi perkembangan zaman melalui dunia pendidikan (Martini, 2018). Dalam dunia pendidikan, kesuksesan seorang siswa tidak hanya terbatas pada kemampuan akademik saja, namun juga dilihat dari kemampuan dan keterampilan yang dapat membantu siswa berkompetensi dalam dunia global dan digital yang berkembang saat ini (Dewi, 2015). Oleh karena itu, pembelajaran yang dilaksanakan guru di kelas harus mampu menyiapkan para siswa agar dapat berkompetisi di masyarakat global (Nahdi, 2019). 
Selain itu, Lubis (Etrina, 2018) berpendapat bahwa pendidikan matematika di abad 21 menuntut sumber daya manusia yang berkualitas, memiliki kemampuan komparatif, inovatif, kompetitif, dan mampu berkolaborasi sehingga mempunyai kemampuan beradaptasi mengahadapi perubahan zaman yang semakin cepat. Untuk menghadapi perubahan yang sangat cepat ini dibutuhkan penguasaan terhadap keterampilan abad 21. Keterampilan abad 21 ini diperlukan oleh seseorang agar berhasil menghadapi tantangan, kehidupan yang semakin kompleks dan penuh dengan ketidakpastian, serta agar berhasil dalam hidup dan karir di dunia kerja. keterampilan abad 21 mencakup 4C yaitu: 1) Critical Thingking and Problem Solving (keterampilan berfikir kritis), 2) Communication Skill (keterampilan komunikasi), 3) Collaborative skill (keterampilan berkolaborasi), 4) creative thingking skill(keterampilan berfikir kreatif).

Tujuan dari penelitian ini adalah untuk mengetahui pengaruh penggunaan pembelajaran matematika realistik berbasis keterampilan abad 21 terhadap hasil belajar siswa kelas VII Mts Muallimat NW Pancor. Adapun pembelajaran matematika realistic berbasis keterampilan abad 21 dapat terlihat dari karakteristik pembelajaran matematika reaslistik menurut Traffers (Wijaya, 2012) sebagai berikut :

1. Menggunakan masalah kontekstual, pada karakter ini siswa diberikan kesempatan untuk menyelesaikan permasalahannya menggunakan apa yang ada disekitarnya atau konteks yang dikenali dan sudah dialami oleh siswa. Hal ini berkaitan dengan keterampilan abad 21 yaitu critical thingking and problem solving.

2. Menngunakan Model, pada karakter ini siswa menggunakan model-model untuk menjembatani pemikiran mereka dari yang abstrak ke yang lebih konkrit. Hal ini sejalan dengan keterampilan abad 21 yaitu creativity and innovation.

3. Menggunakan kontribusi siswa, karakter ini pembelajaran berlangsung lebih mengutamakan kontribusi siswa agar siswa lebih aktif dan mampu menggunakan kemampuannya dengan optimal. Hal ini sejalan dengan keterampilan critical thingking and problem solving, and creativity and innovation.

4. Interaktivitas, dalam karakter ini siswa diberikan untuk berinteraksi dengan optimal baik itu dengan teman-temannya maupun dengan gurunya. Hal ini sejalan dengan keterampilan abad 21 communication and collaboration.

5. Keterkaitan (interwinig), pada karakter ini siswa diberikan kesempatan untuk menghubungkan pemikiran antara materi yang satu dengan materi lainnya baik yang termasuk dalam satu pelajaran maupun pada pelajaran yang lain. Hal ini sejalan dengan keterampilan abad 21 yaitu collaboration.

\section{METODE PENELITIAN}

Jenis penelitian yang digunakan penelitian adalah quasi eksperiment dengan desain peneletian posttest only control group design. Variabel dalam penelitian ini berupa variabel bebas dan variable terikat. Variabel bebas dalam penelitian ini adalah 
pembelajaran matematika realistik berbasis keterampilan abad 21, sedangkan variabel terikat dalam penelitian ini adalah hasil belajar siswa kelas VII MTs Muallimat NW Pancor tahun ajaran 2019/2020. Populasi dalam penelitian ini adalah siswa kelas VII MTs Muallimat NW Pancor yang terdiri dari 6 kelas. Sampel dalam penelitian ini adalah siswa kelas VII A dan siswa kelas VII B. Teknik sampling yang digunakan adalah cluster random sampling (Sugiyono, 2010). Teknik pengumpulan data dalam penelitian ini adalah tes akhir (posttest). Soal posttest terdiri dari 4 soal berupa soal uraian. Validasi yang digunakan pada penelitian ini berupa validitas isi oleh ahli yaitu dosen pendidikan matematika FKIP Universitas Mataram. Uji reliabilitas yang digunakan dalam penelitian ini adalah Cronbach Alpha (Arikunto, 2013). Sedangkan teknik analisis data yang digunakan dalam penelitian ini menggunakan uji-t. sebelumnya dilakukan uji prasyarat yaitu uji normalitas menggunakan uji Lilifors dan uji homogenitas menggunaan uji-Fisher, setelahnya dilakukan uji-t.

\section{HASIL dan PEMBAHASAN}

\subsection{Hasil Penelitian}

1. Uji Validitas

Pengujian instrumen yang dilakukan adalah validitas isi oleh validator ahli yaitu bapak Deni Hamdani, S.Pd, M.Pd selaku dosen pendidikan matematika FKIP Universitas Mataram. Setelah diuji oleh validator ahli, isntrumen soal posttest dinyatakan valid tanpa revisi dan layak digunakan, maka soal posttest tersebut diberikan kepada siswi untuk dijawab.

2. Uji Reliabilitas

Uji reliabilitas ini menggunakan rumus cronbach alpha. Setelah proses perhitungan reliabilitas didapatkan hasil perhitungan reliabilitas terhadap posttes diperoleh koefisien reliabilitas sebesar 0,796 untuk yang kelas kontrol dan 0,791 untuk yang kelas eksperimen. Dengan demikian, dapat dikatakan bahwa instrument penelitian ini reliabel untuk digunakan, karena suatu kuesioner dapat dikatakan reliabel jika nilai Cronbach Alpha's lebih besar dari 0,60 (Arikunto, 2013).

3. Uji Hipotesis

a. Berdasarkan analisis uji normalitas data dengan uji lilifors diperoleh nilai Lhitung untuk kelas eksperimen 0,113 dan Ltabel 0,150 sedangkan nilai Lhitung untuk kelas kontrol 0,104 dan $\mathrm{L}_{\text {tabel }}$ 0,152. Artinya nilai $\mathrm{L}_{\text {hitung }}<\mathrm{L}_{\text {tabel }}$ maka hasil uji normalitas hasil belajar kedua kelas berdistribusi normal.

b. Berdasarkan analisis uji homogenitas dengan uji $\mathrm{F}$ diperoleh nilai $\mathrm{F}_{\text {hitung }}$ adalah 1,07 dan $\mathrm{F}_{\text {tabel }}$ adalah 3,98. Dimana $\mathrm{F}_{\text {hitung }}<\mathrm{F}_{\text {tabel }}$ maka data dari nilai posttest siswa kelas VIIA dan siswa kelas VII B memiliki variansi yang homogen.

c. Pengujian hipotesis menggunakan uji-t digunakan untuk mengetahui apakah pembelajaran atau perlakuan yang dilakukan memiliki pengaruh atau tidak terhadap objek yang diteliti. Diperoleh harga thitung sebesar 2,0921, sedangkan nilai 


\section{Mandalika Mathematics and Education Journal}

Volume 3 Nomor 1, Juni 2021

e-ISSN 2715-1190 | | p-ISSN 2715-8292

DOI: http://dx.doi.org/10.29303/jm.v3i1.1956

$t_{\text {tabel }}$ pada taraf siginifikansi $5 \%$ sebesar 1,1996 . Karena thitung $>t_{\text {tabel }}$ maka $\mathrm{H}_{0}$ ditolak. Oleh karena itu, dapat disimpulkan bahwa terdapat pengaruh pembelajaran matematika realistik berbasis keterampilan abad 21 terhadap hasil belajar siswa kelas VII MTs Muallimat NW Pancor tahun ajaran 2019/2020.

\subsection{Pembahasan}

Hasil belajar adalah perubahan yang mengakibatkan manusia berubah dalam sikap dan tingkah lakunya (Winkel dalam Purwanto, 2010). Hasil belajar menurut Dimyati (2015) adalah hasil dari suatu interaksi tindak belajar dan tindak mengajar. dari sisi guru, tindak mengajar diakhiri dengan proses evaluasi hasil belajar. Sedangkan dari sisi siswa, hasil belajar merupakan berakhirnya penggal dan puncak proses belajar. Sedangkan Nawi (Nur, 2017) berpendapat bahwa hasil belajar matematika adalah kemampuan yang dimiliki siswa yang meliputi kemampuan kognitif, afektif dan psikomotorik sebagai dampak dari proses belajar yang terwujud dalam bentuk nilai yang dilakukan dalam kurun waktu tertentu yang dapat diukur melalui tes.

Ketercapaian ketuntasan belajar yang menggunakan pembelajaran matematika realistik berbasis keterampilan abad 21 sesuai dengan karakteristik yang telah ditetapkan ini tentunya dipengaruhi oleh kegiatan selama proses pembelajaran. Salah satu karakteristik yang mendukung kegiatan siswa selama proses pembelajaran adalah karakteristik interaktivitas dan kontribusi siswa.Pada karakteristik interaktivitas dan kontribusi siswa, siswa dapat melakukan negosiasi, kerjasama, dan diskusi tujuannya agar siswa menjadi lebih aktif dan mampu menggunakan kemampuan yang dimiliknya secara optimal serta dapat menjadikan proses tukar pengalaman antar siswa. Sehingga ketika ada temannya yang memiliki dan menyampaikan pendapat di depan kelas, siswa yang lainnya akan memperhatikan temannya yang lain. Secara tidak langsung kegiatan pembelajaran tersebut akan membuat siswa lebih memahami konsep yang dipelajari, karena siswa biasanya akan lebih cepat mengerti ketika dijelaskan oleh temannya.

Adapun faktor lain yang mendukung tercapainya ketuntasan hasil belajar dalam pembelajaran matematika realistik yaitu diterapkannya keterampilan pendidikan abad 21 dalam pembelajaran ini. Indikator keterampilan pendidikan abad 21 yaitu keterampilan berpikir kritis, kreatif dan inovatif, kerjasama dan komunikasi. Dengan dibentuknya kelompok diskusi saat pembelajaran dapat membentuk kerjasama dan terjadi komunikasi, sehingga siswa yang malu bertanya kepada guru dapat memperoleh informasi dari teman kelompoknya atau bahkan dari kelompok lain.

Keterampilan berfkir kritis dan kreatifitas dan inovasi merupakan hal yang penting yang mendukung tercapainya pembelajaran ini. Ketika dalam proses pembelajaran keterampilan berfikir kritis siswa dapat dilihat dari respon siswa ketika ada teman yang menyampiakan pendapatnya atau mempersentasikan hasil diskusi mereka di depan kelas. Respon siswa dapat berupa pertanyaan atau pendapat mereka sendiri. Hal ini membuat siswa termotivasi dan semangat dalam belajar. Kemudian ketika guru dalam 


\section{Mandalika Mathematics and Education Journal \\ Volume 3 Nomor 1, Juni 2021 \\ e-ISSN 2715-1190| | p-ISSN 2715-8292 \\ DOI: http://dx.doi.org/10.29303/jm.v3i1.1956}

menjelaskan ada kekeliruan saat perhitungan ada beberapa siswa yang cepat tanggap mengkoreksi guru meskipun dalam menyampaikan pendapatnya siswa-siswa tersebut masih terlihat ragu-ragu. Dalam hal ini keterampilan berfikir kritis siswa mulai terlihat.

Sedangkan keterampilan kreatifitas dan inovasi siswa dapat terlihat ketika masingmasing kelompok menyelesaikan permasalahan yang ada di LKPD mereka dengan cara mereka sendiri berdasarkan konsep yang telah mereka temukan dan pembelajaran yang telah mereka terima. Kemudian jawaban-jawaban mereka dikumpulkan dan dibahas serta diperbaiki secara bersama-sama jika masih ada kekeliruan. Hal ini bertujuan agar pengetahuan siswa tidak terbatas.

Dengan diterapkannya pembelajaran matematika berbsasis keterampilan abad 21 pada proses pembelajaran siswa lebih dominan dibandingkan pembelajaran secara langsung, karena saat menggunakan pembelajaran matematika berbasis keterampilan abad 21 guru dituntut hanya sebagai fasilitator saja. Dimana siswa yang sering berdiskusi dengan teman sebangkunya untuk hal-hal tidak penting atau menggangu pelajaran, dapat berdiskusi dengan teman-teman satu kelompoknya untuk hal yang lebih penting, seperti membahas serta mengerjakan tugas kelompok yang diberikan.

\section{PENUTUP}

Berdasarkan hasil analisis data dan pembahasan tentang penerapan pembelajaran matematika realistik berbasis keterampilan abad 21 dapat disimpulkan bahwa terdapat pengaruh pembelajaran matematika realistik berbasis keterampilan abad 21 terhadap hasil belajar siswa kelas VII MTs Muallimat NW Pancor tahun ajaran 2019/2020.

\section{UCAPAN TERIMAKASIH}

Penulisan skripsi ini tidak akan terselesaikan tanpa adanya bimbingan, arahan dan bantuan serta dukungan dari berbagai pihak. Oleh karena itu pada kesempatan ini, penulis mengucapkan terima kasih yang sebesar-besarnya kepada:

1. Dr. H. Wildan, M.Pd, selaku Dekan Fakultas Keguruan dan Ilmu Pendidikan Universitas Mataram.

2. Dr. Drs. Karnan, M.Si, selaku Ketua Jurusan Pendidikan Matematika dan Ilmu Pengetahuan Alam FKIP Universitas Mataram.

3. Drs. H. Baidowi, M.Si, selaku Ketua Program Studi Pendidikan Matematika FKIP Universitas Mataram.

4. Dr. Nyoman Sridana, M.Si selaku Dosen Pembimbing Akademik sekaligus Dosen Pembimbing Pertama Skripsi.

5. Junaidi, S.Pd,M.Pd selaku Dosen Pembimbing Kedua.

6. Drs. H. Baidowi, M.Si, selaku Dosen Penguji Skripsi.

7. Deni Hamdani, S.Pd, M.Pd, selaku validator ahli isntrumen penelitian. 
8. Seluruh dosen di FKIP Universitas Mataram khusunya dosen program studi pendidikan matematika yang telah memberikan bekal ilmu yang sangat berharga kepada penulis selama menjadi mahasiswa.

9. Hj. Baiq Rohmayani, S.Ag, M.Pd, selaku kepala sekolah MTs Muallimat NW Pancor. 10. Sri Pujiani, S.Pd, selaku guru mata pelajaran matematika kelas MTs Muallimat NW Pancor yang telah membantu penulis dalam proses penelitian.

\section{DAFTAR PUSTAKA}

Arikunto, Suharsimi. (2013). Prosedur Penelitian. Jakarta:Rineka Cipta.

Dimyati, dan Mudjiono. (2015). Belajar dan Pembelajaran. Jakarta: Rineka Cipta.

Dewi, Finita. (2015). Proyek Digital Upaya Peningkatan Keterampilan Abad 21 Calon Guru Sekolah Dasar Melalui Model Pembelajaran Berbasis Proyek. Metodik Dedaktik, Vol.9.

Elis Yusimarliah. (2015). Pengaruh Pembelajaran Matematika Dengan Pendekatan Realistik Terhadap Hasil Belajar Peserta Didik. JKPM.

Etrina., Nurul Anriyani., dan Maman Fathurrohman. (2018). Pengembangan Bahan Ajar Matematika Berbasis Kompetensi Abad 21 Untuk Guru Smp/Mts. Jurnal Prosiding Seminar dan Diskusi Nasional Pendidikan Dasar.

Friscilla, Bambang dan Dwi. (2013). Penerapan Pendidikan Matematika Realistik Indonesia Pada Materi Operasi Hitung Bentuk Aljabar Di Kelas VII SMP. FKIP UNTAN.

Martini, Eneng. (2018). Membangun Karakter Generasi Muda Melalui Model Pembelajaran Berbasis Kecakapan Abad 21. Jurnal Pancasila dan Kewarganegaraan, Vol.3, No.2.

Mashuri, Sufri. (2019). Media Pembelajaran Matematika. Yogyakarta: CV Budi Utama.

Nahdi, Dede Salim. (2019). Keterampilan Matematika di Abad 21. Jurnal Cakrawala Pendas, Vol.5, No.2

Nur. (2017). Faktor Stratejik Hasil Belajar Matematika SMP,Skripsi S1 Universitas Muhamadiyah Surakarta.

Purwanto. (2010). Evaluasi Hasil Belajar. Yogyakarta: Pustaka Pelajar.

Sugiyono. (2010). Metodelogi Penelitian Kuantitatif Kualitatif Dan R\&D. Bandung:Alfabeta. Turmuzi, Muhammad. (2012). Strategi Pembelajaran Matematika. Mataram: FKIP UNRAM.

Wijaya, Ariyadi. (2012). Pendidikan Matematika Realistik Suatu Alternatif Pendekatan Pembelajaran Matematika. Yogyakarta: Graha Ilmu.

Wina, Sanjaya. (2017). Paradigma Baru Mengajar. Jakarta: KENCANA. 